\title{
HIV Care Continuum from diagnosis in a Counseling and Testing Center
}

\author{
Cascata do cuidado do HIV a partir do diagnóstico em Centro de Testagem e Aconselhamento \\ Cascada del cuidado del VIH a partir del diagnóstico en Centro de Pruebas y Consejo
}

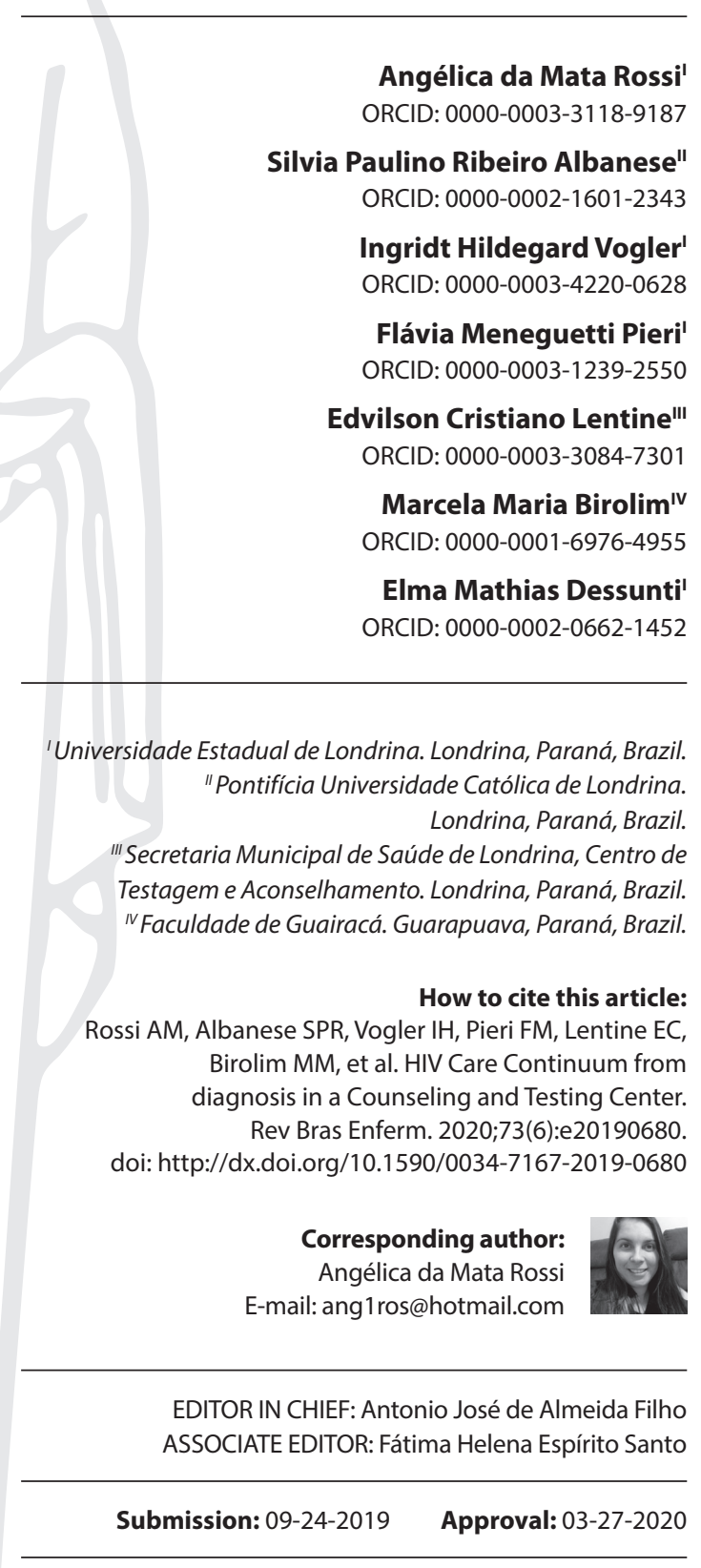

\begin{abstract}
Objective: To analyze the HIV care continuum from the diagnosis in an HIV/AIDS Counseling and Testing Center (CTC), and the sociodemographic, clinical, and laboratory characteristics related to gender. Method: Epidemiological study, conducted with data of individuals assisted at a Counseling and Testing Center, and followed in an outpatient clinic for HIV/AIDS Pearson's Chi-square test and binary logistic regression were used to obtain odds ratios, considering alpha value $<0.05$. Results: The prevalence of HIV among 5,229 users was $5 \%$. The highest chance of positive results was among men, aged 14 to 33 years old, who were not in a domestic partnership. In the analysis of TCD4+ lymphocytes and viral load (VL) of 238 cases, $56.1 \%$ had a late diagnosis. We have identified gaps in the care cascade, especially linkage to the care, retention in care, and viral load suppression. Conclusion: The results suggest a late diagnosis for both genders, as well as difficulty in reaching the viral suppression goal.

Descriptors: HIV Infections; Early Diagnosis; Treatment Outcome; Continuity of Patient Care; Epidemiology
\end{abstract}

\section{RESUMO}

Objetivo: Analisar a cascata do cuidado do HIV a partir do diagnóstico em Centro de Testagem e Aconselhamento (CTA); e as características sociodemográficas, clínicas e laboratoriais relacionadas ao sexo. Método: Estudo epidemiológico, realizado com dados de indivíduos atendidos num Centro de Testagem e Aconselhamento e acompanhados em ambulatório de HIV/aids. Foram utilizados o teste Qui-quadrado e regressão logística binária, para obtenção do odds ratio, considerando alfa < 0,05. Resultados: A prevalência de HIV nos 5.229 usuários foi de 5\%, com maior chance de resultado positivo entre homens, faixa etária de 14 a 33 anos, que não apresentavam união estável. Na análise de linfócitos TCD4+ e carga viral (CV) de 238 casos, 56,1\% realizaram diagnóstico tardio. Foram identificadas lacunas na cascata do cuidado, especialmente na vinculação, retenção no cuidado e supressão da carga viral. Conclusão: Os resultados sugerem diagnóstico tardio para ambos os sexos, além de dificuldade em alcançar a meta de supressão viral.

Descritores: Infecções por HIV; Diagnóstico Precoce; Resultado do Tratamento; Continuidade da Assistência ao Paciente; Epidemiologia.

\section{RESUMEN}

Objetivo: Analizar la cascada del cuidado del VIH a partir del diagnóstico en Centro de Pruebas y Consejo (CTA); y las características sociodemográficas, clínicas y laboratoriales relacionadas al sexo. Método: Estudio epidemiológico, realizado con datos de indivíduos atendidos en un Centro de Pruebas y Consejo y acompañados en ambulatorio de $\mathrm{VIH} / \mathrm{sida}$. Han sido utilizados el test chi cuadrado y regresión logística binaria, para obtención del odds ratio, considerando alfa $<0,05$. Resultados: La prevalencia de VIH nos 5.229 usuarios ha sido de $5 \%$, con mayor chance de resultado positivo entre hombres, franja etaria de 14 a 33 años, que no presentaban unión estable. En el análisis de linfocitos TCD4+y carga viral (CV) de 238 casos, 56,1\% realizaron diagnóstico tardío. Han sido identificadas lagunas en la cascada del cuidado, especialmente en la vinculación, retención en el cuidado y supresión de la carga viral. Conclusión: Los resultados sugieren diagnóstico tardío para ambos los sexos, además dificultad en alcanzar la meta de supresión viral.

Descriptores: Infecciones por VIH; Diagnóstico Precoz; Resultado del Tratamiento; Continuidad de la Asistencia al Paciente; Epidemiología. 


\section{INTRODUCTION}

Access to testing and counseling contributes to the early diagnosis and treatment of infection by the human immunodeficiency virus (HIV) and to control its transmission. To this end, the Testing and Counseling Centers (CTC) in Brazil offer rapid tests (RT) for the diagnosis of HIV and other infections such as syphilis and hepatitis $B$ and $C^{(1)}$.

The 2030 Sustainable Development Agenda proposed by the Joint United Nations Program on HIV/AIDS (UNAIDS) includes the global challenge of eradicating the AIDS epidemic by $2030^{2}$. The 90-90-90 goal establishes that by $2020,90 \%$ of people living with HIV are aware of their HIV status, $90 \%$ of diagnosed people receive antiretroviral therapy (ART), and $90 \%$ of people undergoing treatment have an undetectable viral load $(\mathrm{VL})^{(2)}$. The expansion of the offer of HIV testing in the Brazilian public health system favors access to diagnosis, without, however, guarantee that it occurs at an early stage of infection.

The cascade of continuous HIV care is one of the clinical monitoring strategies that portrays the trajectory of people living with HIV/AIDS (PLWHA) in health services, from diagnosis to viral suppression. It includes five stages: diagnosis, linkage to the health service, retention in care, adherence to ART, and viral suppression ${ }^{(3-4)}$. The diagnosis of HIV is the first challenge of goal 90-90-90, culminating in viral suppression, obtained with the regular use of ART. Brazil offers this therapy for free, placing the country as a model for the world. The cascade of HIV care shows that, by the end of $2018,85 \%$ of PLWHA were diagnosed in Brazil, $66 \%$ were under treatment, and $62 \%$ had viral suppression ${ }^{(5)}$. This data shows that access to diagnosis appears to be effective; however, the stage of infection in which this occurs is still late for $27 \%$ of individuals, especially in the most vulnerable population groups. Among young Brazilians, for example, the number of cases of HIV infection continues to increase ${ }^{(5)}$.

The care continuum based on the diagnosis of HIV allows the analysis of the data considering some variables of interest, which makes it possible to verify from the early diagnosis to viral suppression, from a gender perspective. One study lists hegemonic masculinity as a contributing factor for heterosexual men to present themselves as invulnerable, resulting in irregular condom use and not seeking HIV testing ${ }^{(6)}$. Besides, the presence of infection symptoms was the most cited reason for HIV testing among the male population in a Brazilian state, characterizing a late diagnosis ${ }^{(7)}$. In southern Africa, a study has shown that men are more likely to seek treatment later (CD4+T L $\leq 200$ cells $/ \mu \mathrm{L})$ than women, compared to early search (CD4+ T L $\geq 500$ cells/ $\mu \mathrm{L})^{(8)}$. A study that analyzes factors to explain how masculinity constitutes a social determinant of health points to a lower association in the adoption of health promotion and prevention actions among men and, also, less demand for health services ${ }^{(9)}$.

Studies show that individuals are making a late diagnosis of HIV infection when admitted to specialized health services ${ }^{(7,10-11)}$ without, however, identifying the location of the diagnostic exam. Among the suggested interventions, there is the expansion of the opening of CTCs, with RT enforcement to improve access to diagnosis ${ }^{(7)}$.

Considering the exposed data and the few studies that analyze the care cascade from CTC, especially related to sex, we question:
What is the viral load at the time of diagnosis and follow-up? Is the diagnosis of HIV infection at a CTC being performed early, contributing to reaching the final goal of viral load suppression care cascade? Are there differences between genders?

Thus, we consider relevant to survey the cases diagnosed in the CTC and search for them in HIV/AIDS specialized care services, including data that allow indicating whether access to diagnosis is occurring at an early stage, as well as the implementation of therapeutic measures to the extent of viral suppression.

\section{OBJECTIVE}

To analyze the HIV care continuum from the diagnosis in the Testing and Counseling Center; and the sociodemographic, clinical, and laboratory characteristics related to gender.

\section{METHODS}

\section{Ethical aspects}

This study was approved by the local Research Ethics Committee, meeting the requirements of Resolution 466/2012 of the National Health Council.

\section{Study Design, setting, and period}

An epidemiological, descriptive study carried out in a Reference Center for HIV/AIDS in a large city in southern Brazil, which includes the CTC and the HIV/AIDS outpatient clinic. These services are part of the municipality's health network, which is the headquarters of a metropolitan region. The CTC provides for spontaneous demand, offering RTs for HIV, syphilis, and hepatitis B and C. It also refers positive cases to the HIV/AIDS outpatient clinic for monitoring and dispensing ART. However, some individuals choose to do the follow up on the private network. Another service location in the municipality is the local public university outpatient clinic, whose service is restricted to approximately 300 patients, most of whom are incorporated after an intrahospital diagnosis. The survey data are from June 2012 to June 2015.

\section{Population or sample; inclusion and exclusion criteria}

The study population comprised users who sought the CTC to perform RT for HIV. To obtain the sample, we started with the CTC service record, excluding repeated entries, inconclusive results, cases with no HIV test doing, and, among those who underwent HIV testing, the negative cases. The study excluded positive cases whose medical records were not found.

\section{Study Protocol}

For the analysis of sociodemographic characteristics, data from the CTC Information System (SI-CTA) were used; and for the collection of clinical and laboratory data, the outpatient medical records were used. We consulted the results of the VL and CD4+ T lymphocyte tests in the Sistema de Controle de Exames Laboratoriais (SISCEL- Laboratory Examination Control System), which allowed more accurate monitoring of the patients'immunological and virological status until June 2018. 
The instrument used included the independent variables: sociodemographic (age, education, race/color, marital status), initial clinical situation (symptoms, coinfections, other STIs and comorbidities), serologies performed at the service admission results (cytomegalovirus, toxoplasmosis, syphilis, and hepatitis $A, B$ and $C$ ), virologic and immunological status (initial count and monitoring of $\mathrm{VL}$ and $\mathrm{CD} 4^{+} \mathrm{T}$ lymphocytes).

The care continuum construction based on the diagnosis, showing each step as a percentage of the number of PLWHA diagnosed ${ }^{(4)}$. The user was assessed as linked to care when there was in the medical record the first consultation attendance within a period of up to 30 days after diagnosis. We evaluated the use of ART in case there was a note about the beginning of this treatment in the medical record, being characterized as "regular follow-up" when the user had attended at least one consultation or had undergone a VL examination or $C D 4^{+} \mathrm{T} L$ count per year, in the period selected for the study. We considered as suppressed VL or presence of virologic response when the $V L$ result was less than 50 copies/mL. The immune response was present when the $\mathrm{CD}^{+}{ }^{+} \mathrm{T}$ lymphocyte count was greater than 350 cells/ $\mu \mathrm{L}$.

The diagnosis was interpreted as late when in the first examination performed, the VL was above 100,000 copies $/ \mathrm{mL}$, regardless of the $\mathrm{CD}^{+} \mathrm{T}$, since this condition indicates a high possibility of progression to AIDS. Likewise, the $C D 4^{+} T L$ count of fewer than 350 cells $/ \mu \mathrm{L}$, regardless of viral load, was also considered as a late diagnosis ${ }^{(12)}$.

\section{Results analysis and statistics}

In the data analysis, the program Statistical Package for the Social Sciences (SPSS), version 20.0 was used, with the calculation of absolute and relative frequency for the categorical variables and measures of central tendency and dispersion (median and interquartile deviation - IQR - 25\% -75\%) for continuous variables. As a way of comparing continuous variables, we assessed the normality of the distribution of these variables using the Shapiro-Wilk test and analyzed the non-parametric results using the Mann Whitney U test. Pearson's chi-square test was used to compare categorized data and the binary logistic regression to obtain the odds ratio (OR) and 95\% confidence interval (95\% $\mathrm{CI})$. The analyzes were stratified by gender, considering a $95 \%$ confidence level and an alpha value $<0.05$.

\section{RESULTS}

We identified 6,566 consultations carried out at the CTC. We excluded repeated entries $(1,256)$, inconclusive results $(4)$, and cases with no HIV test doing (77), reaching a total of 5,229 individuals who presented defined HIV test results. The prevalence of positivity was $5.0 \%$ (259), of which $78 \%$ were male. Patients were followed up after diagnosis for a median of 46 months (IQR: 35-57) and had tests performed every eight months (IQR: 7-10). The women's age ranged from 14 to 67 years old (median: 35 years; IQR: 27-46), while for men it ranged from 16 to 68 years old (median: 30 years; IQR: 24-38), with a different distribution between the genders $(p=0.022)$.

The analysis of the medical records at the outpatient clinic recorded losses of 21 non-localized medical records, possibly related to visits to other public or private services. The analysis of laboratory tests at SISCEL also included the loss of 15 registrations, possibly due to abandonment or conducting tests on the private network. Thus, the study analyzed 259 records regarding sociodemographic aspects, 244 laboratory aspects, and 238 records concerning clinical aspects and the stage of infection in which the diagnosis occurred.

It was possible to observe the highest chance of positivity among younger men (14 to 33 years old), with higher education and who were not in a domestic partnership. Among women, the age of 34 to 68 years old prevailed, with a higher chance for those with less education and in a domestic partnership (Table 1).

Table 1 - Distribution of individuals with HIV positive results in a Testing and Counseling Center, according to sex and sociodemographic variables $(n=259)$

\begin{tabular}{|c|c|c|c|c|c|c|c|c|}
\hline \multirow{2}{*}{$\begin{array}{l}\text { Characteristics } \\
\text { Sociodemographic }\end{array}$} & \multicolumn{2}{|c|}{ Male } & \multicolumn{2}{|c|}{$\begin{array}{l}\text { Gender } \\
\text { Female }\end{array}$} & \multicolumn{2}{|c|}{ Total } & \multirow[t]{2}{*}{ OR $(95 \% \mathrm{Cl})$} & \multirow[t]{2}{*}{$p$ value } \\
\hline & $\mathbf{n}$ & $\%$ & $\mathbf{n}$ & $\%$ & $\mathbf{n}$ & $\%$ & & \\
\hline \multicolumn{9}{|l|}{ Age group } \\
\hline 14 to 33 years old & 131 & 64.9 & 27 & 47.4 & 158 & 61.0 & $2.05(1.13-3.72)$ & 0.018 \\
\hline 34 to 68 years old & 71 & 35.1 & 30 & 52.6 & 101 & 39.0 & $1: 00$ & \\
\hline \multicolumn{9}{|l|}{ Education in Years $(\mathrm{n}=258)^{*}$} \\
\hline 0 to 7 & 69 & 34.2 & 33 & 58.9 & 102 & 39.5 & $1: 00$ & 0.001 \\
\hline 8 and more & 133 & 65.8 & 23 & 41.1 & 156 & 60.5 & $2.77(1.51-5.07)$ & \\
\hline \multicolumn{9}{|l|}{ Race/color $(n=256) *$} \\
\hline White & 160 & 79.6 & 43 & 78.2 & 203 & 79.3 & $1.09(0.53-2.25)$ & 0.818 \\
\hline Non-white & 41 & 20.4 & 12 & 21.8 & 53 & 20.7 & $1: 00$ & \\
\hline \multicolumn{9}{|l|}{ Marital status $(n=256)^{*}$} \\
\hline Domestic Partnership & 49 & 24.5 & 30 & 53.6 & 79 & 30.9 & 1:00 & $<0.001$ \\
\hline Not in a domestic partnership & 151 & 75.5 & 26 & 46.4 & 177 & 69.1 & $3.56(1.92-6.58)$ & \\
\hline
\end{tabular}

Serologies for cytomegalovirus $\lg G$ and toxoplasmosis $\lg G$ were very high, with some cases of IgM positive. Also, 29.3\% of patients who underwent a treponemal test (FTA-Abs) had a positive result, having been confirmed by VDRL in $24.4 \%$ of the cases. Regarding hepatitis, the serology with the highest positivity was type $A$, with a higher percentage among women. The HBsAg screening was reactive in $2.1 \%$ of the cases (Table 2 ).

Of the medical records that mentioned the presence or absence of symptoms, in half of them, there was a note of some that could be related to AIDS. The presence of co-infections and other STIs was more reported among men (Table 3 ).

The initial CD4+ $T L$ count for men $(n=190)$ ranged from 4 to 1,373 cells/ $\mu \mathrm{L}$ of blood, with a median of 444 cells/ $\mu \mathrm{L}$ (IQR: 253 669). Whereas for women ( $n=55)$, it ranged from 12 to 1,107 cells/ $\mu \mathrm{L}$, a median of 422 cells/ $\mu \mathrm{L}$ (IQR: 271-682). The study showed no difference between genders $(p=0.875)$. The last $C D 4^{+} T L$ count test had a median of 624 cells/ $\mu \mathrm{L}$ (IQR: 395-868) for men and 575 cells/ $\mu$ L (IQR: 447824) for women ( $p=0.598)$.

The VL at the time of diagnosis reached a maximum of 5,793,753 copies/mL of blood (median: 52,286 copies/mL, IQR: 12,538182,926) among men and 4,232,486 copies/mL (median: 39,297 
copies/mL ; IQR: 5,972-320,442) among women, with no difference between genders $(p=0.604)$. In the last VL examination recorded in the patients' follow-up, there was suppressed $V L$ results predominance $(<50$ copies $/ \mathrm{mL})$ for both genders $(p=0.455)$.

Table 2 - Distribution of individuals with positive results for HIV in a Testing and Counseling Center, according to gender and laboratory tests with positive results in the first test $(n=238)^{*}$

\begin{tabular}{|c|c|c|c|c|c|c|}
\hline \multirow{3}{*}{ Exames } & \multicolumn{4}{|c|}{ Gender } & & \\
\hline & \multicolumn{2}{|c|}{ Male } & \multicolumn{2}{|c|}{ Female } & \multicolumn{2}{|c|}{ Total } \\
\hline & $\mathbf{n}$ & $\%$ & $\mathbf{n}$ & $\%$ & $\mathbf{n}$ & $\%$ \\
\hline \multicolumn{7}{|l|}{ Cytomegalovirus } \\
\hline $\lg G\left(130^{*}\right)$ & 91 & 96.8 & 35 & 97.2 & 126 & 96.7 \\
\hline $\lg M\left(118^{*}\right)$ & 03 & 3.4 & - & - & 03 & 2.5 \\
\hline \multicolumn{7}{|l|}{ Toxoplasmosis } \\
\hline $\lg G\left(145^{*}\right)$ & 51 & 47.7 & 25 & 65.8 & 76 & 52.4 \\
\hline $\lg M\left(141^{*}\right)$ & 05 & 4.8 & 01 & 2.7 & 06 & 4.3 \\
\hline \multicolumn{7}{|l|}{ Syphilis } \\
\hline FTA-Abs $\left(182^{*}\right)$ & 50 & 36.0 & 03 & 7.0 & 53 & 29.1 \\
\hline VDRL $\left(172^{*}\right)$ & 41 & 31.1 & 01 & 2.5 & 42 & 24.4 \\
\hline ANTI-HAV $\left(123^{*}\right)$ & 55 & 62.5 & 30 & 85.7 & 85 & 69.1 \\
\hline AntI-HCV $\left(190^{*}\right)$ & 02 & 1.4 & 02 & 4.4 & 04 & 2.1 \\
\hline \multicolumn{7}{|l|}{ Hepatitis B } \\
\hline HBsAg $\left(195^{*}\right)$ & 03 & 2.1 & 01 & 2.0 & 04 & 2.1 \\
\hline
\end{tabular}

Table 3 - Distribution of individuals with HIV positive results in a Testing and Counseling Center, according to gender and clinical status $(n=259)^{*}$

\begin{tabular}{|c|c|c|c|c|c|c|c|}
\hline \multirow{3}{*}{ Clinical Status } & \multicolumn{4}{|c|}{ Gender } & \multirow{2}{*}{\multicolumn{2}{|c|}{ Total }} & \multirow{3}{*}{$p$ value } \\
\hline & \multicolumn{2}{|c|}{ Male } & \multicolumn{2}{|c|}{ Female } & & & \\
\hline & $\mathbf{n}$ & $\%$ & $\mathbf{n}$ & $\%$ & $\mathbf{n}$ & $\%$ & \\
\hline \multicolumn{8}{|c|}{ Symptoms $\left(n=210^{*}\right)$} \\
\hline Yes & 82 & 50.0 & 23 & 50.0 & 105 & 50.0 & \multirow[b]{2}{*}{$0.566^{* * *}$} \\
\hline No & 82 & 50.0 & 23 & 50.0 & 105 & 50.0 & \\
\hline \multicolumn{8}{|c|}{ Coinfections $\left(177^{*}\right)$} \\
\hline Yes & 101 & 68.7 & 20 & 47.6 & 121 & 64.0 & \multirow[b]{2}{*}{$0.012^{* *}$} \\
\hline No & 46 & 31.3 & 22 & 52.4 & 68 & 36.0 & \\
\hline \multicolumn{8}{|c|}{ Other STIs $\left(n=108^{*}\right)$} \\
\hline Yes & 80 & 80.8 & 10 & 55.6 & 90 & 76.9 & \multirow[b]{2}{*}{$0.031^{* * *}$} \\
\hline No & 19 & 19.2 & 8 & 44.4 & 27 & 23.1 & \\
\hline \multicolumn{8}{|c|}{ Comorbidities $\left(n=145^{*}\right)$} \\
\hline Yes & 30 & 25.4 & 12 & 31.6 & 42 & 26.9 & \multirow[b]{2}{*}{$0.457^{* *}$} \\
\hline No & 88 & 74.6 & 26 & 68.4 & 114 & 73.1 & \\
\hline
\end{tabular}

Note: *Excluded ignored cases/not applicable and when there was no mention in the medical record * Pearson's chi-square test. ***Fisher's exact test.

Table 4 - Distribution of individuals with HIV positive results in a Testing and Counseling Center, according to CD4 ${ }^{+} \mathrm{T}$ lymphocytes results and Viral Load $(n=244)^{*}$

\begin{tabular}{|c|c|c|c|c|c|c|c|c|}
\hline & \multicolumn{6}{|c|}{ Viral Load (copies/ML) } & & \\
\hline & \multicolumn{2}{|c|}{$<50$} & \multicolumn{2}{|c|}{$50-100.000$} & \multicolumn{2}{|c|}{$\geq 100.000$} & \multicolumn{2}{|c|}{ Total } \\
\hline & $\mathbf{n}$ & $\%$ & n & $\%$ & n & $\%$ & n & $\%$ \\
\hline \multicolumn{9}{|c|}{$1^{\text {ST }}$ Examination } \\
\hline \multicolumn{9}{|l|}{$\mathrm{CD}^{+} \mathrm{T} \mathrm{L} / \mu \mathrm{L}$} \\
\hline$<200$ & 0 & 0.0 & 17 & 7.0 & 31 & 12.7 & 48 & 19.7 \\
\hline 200 to 349 & 1 & 0.4 & 29 & 11.9 & 13 & 5.3 & 43 & 17.6 \\
\hline 350 to 499 & 0 & 0.0 & 30 & 12.3 & 18 & 7.4 & 48 & 19.7 \\
\hline$\geq 500$ & 5 & 2.0 & 74 & 30.3 & 26 & 10.7 & 105 & 43.0 \\
\hline Total & 6 & 2.4 & 150 & 61.5 & 88 & 36.1 & 244 & 100.0 \\
\hline \multicolumn{9}{|c|}{$\begin{array}{l}\text { Last Examination } \\
\mathrm{CD}^{+} \mathrm{T} \mathrm{L} / \mu \mathrm{L}\end{array}$} \\
\hline$<200$ & 0 & 0.0 & 6 & 2.5 & 17 & 7.0 & 23 & 9.4 \\
\hline 200 to 349 & 9 & 3.7 & 7 & 2.9 & 1 & 0.4 & 17 & 7.0 \\
\hline 350 to 499 & 28 & 11.5 & 17 & 7.0 & 2 & 0.8 & 47 & 19.3 \\
\hline$\geq 500$ & 127 & 52.0 & 29 & 11.9 & 1 & 0.4 & 157 & 64.3 \\
\hline Total & 164 & 67.2 & 59 & 24.2 & 21 & 8.6 & 244 & 100.0 \\
\hline
\end{tabular}

Table 4 shows that, at the time of diagnosis, $37.3 \%$ of the individuals had a CD4 ${ }^{+} \mathrm{T} L$ count below 350 cells $/ \mu \mathrm{L}$. In cases where the lymphocyte count was greater than or equal to 350 cells $/ \mu \mathrm{L}, 18.1 \%$ had a VL above 100,000 copies $/ \mathrm{mL}$ of blood. In the follow-up, we noted that $63.5 \%$ of the patients started to have suppressed VL ( $<50$ copies $/ \mathrm{mL}$ ) and CD4 ${ }^{+} \mathrm{T} L$ above 350 cells $/ \mu \mathrm{L}$.

Figure 1 shows the care continuum based on the diagnosis of HIV in a CTC ( $n=259$ individuals). The percentage of individuals received for care within 30 days of diagnosis was $61.9 \%$ for males and $66.7 \%$ for females. After this period, other individuals came to the service, having been prescribed ART for $87.6 \%$ of men and $93 \%$ of women during the entire study period. However, only $58.4 \%$ and $57.9 \%$ of men and women, respectively, were retained in care. We verified the suppressed VL in $64.9 \%$ and $59.6 \%$ of the cases diagnosed for men and women, respectively, with no difference between genders $(p=0.296)$.

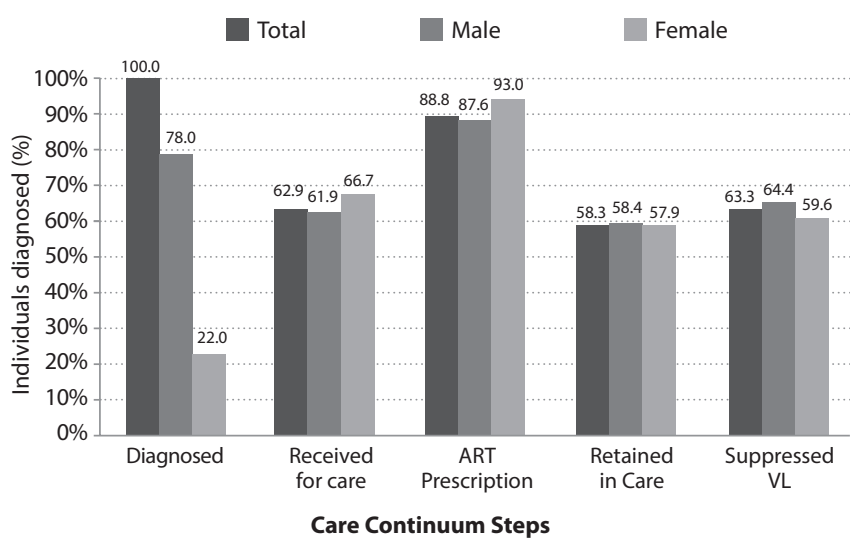

Note: $A R T$ - antiretroviral therapy; VL - viral load.

Figure 1 - Care continuum for HIV-positive individuals, whose test was carried out in a Testing and Counseling Center in Southern Brazil, from 2012 to 2018

\section{DISCUSSION}

In the analysis of the 259 cases diagnosed with HIV (5\%), we observed that the chance of positivity was greater among men, the youngest, and the ones with higher education. The profile of the HIV/AIDS epidemic in Brazil shows a higher prevalence among men, the male/female ratio of 2.6: 1 in 2017. However, in the southern region of the country, this study location, there is greater participation of women in the AIDS reported cases, with a proportion of $1.8: 1$, in the same year ${ }^{(13)}$

Despite the higher rates among men, the reduction in the male/female ratio observed in some states reflects power relations based on female submission concerning decision-making to adopt preventive measures ${ }^{(14)}$ and difficulty in negotiating condom use with partners ${ }^{(15)}$. Besides, a 1.5-fold increase in susceptibility to HIV infection is observed in women who suffer physical or sexual violence in some regions ${ }^{(16)}$. A qualitative study with the female population showed that they consider other women vulnerable to HIV. However, they do not include themselves in this risk perception, which contributes to non-prevention and late diagnosis ${ }^{(17)}$.

The demand for the HIV test has been low, especially among women, a fact confirmed by a population-based survey in which the prevalence of spontaneous testing was $13.6 \%$, being associated, above all, with the prenatal routine and inadequate risk perception ${ }^{(18)}$. 
Younger men were the ones who most sought the HIV test and also the most affected by the infection. Among women, positivity was higher in the age group above 34 years old. However, the younger female population had a considerable percentage related to infection, similar to a study with HIV positive adults that indicates a tendency for the infection to affect younger people ${ }^{(19)}$.

Regarding education, men with HIV had more years of study when compared to women. A higher level of education may be related to greater access to diagnostic testing. Some studies associated low educational level with individuals with HIV ${ }^{(15,20)}$.

Men who were not in domestic partnerships were more likely to be diagnosed with HIV than women, which may be related to not using condoms, as shown by a study conducted with PLWHA, of whom singles were less likely to use condoms when compared to individuals in domestic partnerships ${ }^{(15)}$. However, among married people, the use of condoms is often dispensed, as individuals, especially women, consider domestic partnerships as a protective factor against infection due to trusting their partners ${ }^{(17)}$.

White race/color prevailed among HIV positive cases, which reflects the profile of the population of the municipality of the study.

Parameters such as CD4 ${ }^{+}$T lymphocyte and VL count indicate that the diagnosis was late for most of the individuals surveyed. According to the Center for Diseases Control and Prevention, the criterion for evidence of immunodeficiency considers the $\mathrm{CD}^{+} \mathrm{T} \mathrm{L}$ count $<350$ cells/ $\mu \mathrm{L}$. The progression of HIV infection worsens by the presentation of atypical infections, late response to antibiotic therapy, and reactivation of latent infections s $^{(3,21)}$.

Considering the stages of HIV infection proposed by the $\mathrm{CDC}^{(22)}$, $43 \%$ of users in this study were in phase 1 (CD4 ${ }^{+} \mathrm{T} \geq 500$ cells/ $\mu \mathrm{L}) ; 37.3 \%$, in phase 2 (CD4 ${ }^{+} \mathrm{T}=200$ to 499 cells $\left./ \mu \mathrm{L}\right)$; and $19.7 \%$, in phase $3\left(\mathrm{CD}^{+} \mathrm{T}<200\right.$ cells $\left./ \mu \mathrm{L}\right)$. These parameters assist in the conduct necessary to control infection and associated diseases. However, the onset of ART should be encouraged, regardless of the $\mathrm{CD}^{+} \mathrm{T}$ count, to reduce the transmissibility of $\mathrm{HIV}^{(3)}$.

A study carried out in a Brazilian reference center showed that, upon admission to the service, more than half (52\%) of HIV positive users had a CD4+ T lymphocyte count below 200 cells $/ \mu \mathrm{L}$ and the presence of at least one AIDS-defining disease $\mathrm{e}^{(7)}$.

Late diagnosis and subsequent postponed treatment can impact the individual and society. A study carried out in Brazil, investigated the survival determinants of 269,076 PLWHA, who started ART from 2006 to 2015 . The authors concluded that the risk of death in the first six months decreased with the early start of treatment, that is, for starting ART with $C D 4^{+} \mathrm{T} \geq 500$ cells/ $\mu \mathrm{L}$, the risk rate was $0.06(95 \% \mathrm{Cl} \% 0.05-0.07)$ compared to $\mathrm{CD}^{+} \mathrm{T}$ $<200$ cells $/ \mu L^{(23)}$.

It is also necessary to consider the VL count, as its increase is proportional to the drop in the lymphocyte count. In this study, $18.1 \%$ had a VL greater than 100,000 copies/mL of blood, even with CD4 ${ }^{+} \mathrm{T}$ still above 350 cells $/ \mu \mathrm{L}$, which indicates a high possibility of progression to AIDS ${ }^{(12)}$. We observed severe results, for both lymphocytes, with a minimum of 4 , and VL, with a maximum of 5,793,753 copies $/ \mathrm{mL}$, which translates to a late diagnosis of the infection.

A study carried out in Bahia, Brazil, found a high index of individuals with signs of immunodeficiency or opportunistic infection and $\mathrm{CD}^{+}{ }^{+} \mathrm{T}$ lymphocytes $<200$ cells/ $\mu \mathrm{L}$, suggesting that there are barriers to timely access to diagnosis and treatment ${ }^{(24)}$.
The initial VL was undetectable in three patients, indicating that, probably, these individuals had already started ART or could be included in the small group of so-called "elite controllers," that is, HIV-infected people who maintain plasma levels of VL below the level of quantification for years, without the use of $\mathrm{ART}^{(3)}$.

The study showed elevated immunoglobulins (lg) for cytomegalovirus (lgG) and toxoplasmosis (lgG). In cases of lgG positive for toxoplasmosis, it is recommended to evaluate the $\mathrm{CD}^{+} \mathrm{T}$ cell count to carry out prophylactic medication, as the risk of opportunistic infection links to the level of these defense cells. For individuals with lgG positive for cytomegalovirus, primary prophylaxis is not recommended, only secondary prophylaxis ${ }^{(3)}$. IgMs were positive for cytomegalovirus and toxoplasmosis in three and six cases, respectively, when there is a recommendation to start treatment and control since they are considered AIDS-defining diseases ${ }^{(3)}$. A study carried out with 547 people infected with HIV identified a higher prevalence of IgG and IgM anti-Toxoplasma gondii (69\% and $6 \%$, respectively) concerning this research ${ }^{(25)}$.

Syphilis showed significant positivity in relation to the FTA-Abs and VDRL tests, especially among men. This study did not consider the clinical stage of syphilis. In analyzing the medical records, we observed that, in some cases, the diagnosis for HIV occurred from the investigation and initial detection of this STI. A study carried out in Belo Horizonte indicated that individuals with syphilis were less likely to have late treatment/diagnosis of $\mathrm{HIV}^{(26)}$.

In relation to the serology performed for hepatitis, there was a higher prevalence of hepatitis A. The HBsAg, and anti-HVL markers showed a reagent result of $2.1 \%$ for each type. This study did not investigate other serological markers, so it is not clear whether the user had an acute or chronic infection. It is known that patients with hepatitis respond poorly to ART, with a risk of progressing to complicated chronic liver disease ${ }^{(3)}$.

About half of the users whose medical records had notes on the presence or absence of symptomatology reported some indication of AIDS. A study in the north of the country showed that the most frequent reason for testing was the presentation of signs and symptoms related to $\mathrm{HIV}^{(7)}$.

The presence of coinfections and other STIs was more reported among men. The early diagnosis of HIV infection, with immediate start of treatment, is of paramount importance to improve the immune system, possibly culminating in the control of coinfections. We emphasize the need to treat STIs since they facilitate the transmission of the virus through ulcers and inflammation in the genitalia. Comorbidities were similar for both genders, and the most identified were diabetes, high blood pressure, and dyslipidemia. We point out that HIV infection and the use of ART predispose to some comorbidities. Research conducted with PLWHA indicates a much higher prevalence of comorbidities than those presented in this study. Among them, dyslipidemia stands out ${ }^{(27)}$.

Regarding the care continuum, we found that the user's attachment to the first consultation at the outpatient clinic occurred, in the majority, with less than 30 days between the diagnosis and the beginning of the monitoring. However, a high percentage of users started monitoring at the clinic after that period. According to Avaliação e Monitoramento da Qualidade da Assistência Ambulatorial em aids no SUS (Qualiaids - Evaluation and Monitoring of the Quality of AIDS Outpatient Care in SUS), 
the person diagnosed with HIV must be promptly referred to the referral service for medical consultation. If it is not possible to schedule this appointment, another professional must host and request routine tests, mainly $\mathrm{CD}^{+}{ }^{+} \mathrm{T}$ lymphocyte count and $\mathrm{VL}$, so that they are available at the first medical appointment ${ }^{(28)}$.

Individuals who took longer to start monitoring are offered strategies to improve access and linkage of these individuals to the specialized service. The adoption of stigmatizing or discriminatory attitudes and practices by health systems or professionals to PLWHA contributes to these people having less access to services, making it difficult to control the infection. In order to minimize this situation, PLWHA networks and organizations have been working with local, national and international partners to strengthen coordination capacity, empower PLWHA, raise awareness among health professionals and contribute to the development of laws, policies, and programs that reduce discrimination and increase access to the main services ${ }^{(29)}$.

After diagnosis and first access to services, PLWHA should begin clinical and therapeutic monitoring. It is necessary to offer treatment as early as possible, regardless of $V L$ and $C D 4^{+} T L$ values, as it contributes to the VL suppression and transmission reduction $^{(2)}$. This study showed that, for $88.8 \%$ of the diagnosed cases, there was a prescription of ART, with a higher percentage among women. However, VL suppression occurred in 63.3\% (164/259) of diagnosed cases and $71.3 \%$ (164/230) of cases in which ART was prescribed, with no difference between genders. These percentages do not contemplate the $90-90-90$ goal proposed by UNAIDS to achieve $90 \%$ of VL suppression among individuals using ART. Some factors contribute to low adherence to ART, as younger individuals $\mathbf{s}^{(24,30)}$, lower education ${ }^{(24,30-31)}$, adverse reactions to medication ${ }^{(24)}$, alcohol and drug use ${ }^{(24,31)}$, history of treatment abandonment, exposure to HIV and difficulty in accessing the service ${ }^{(31)}$. In analyzing adherence in two aspects, a study shows that the interruption of ART for three months was significantly related to older age, while the loss of doses (interruption for one week) was related to younger individuals, and may reflect aspects of the lifestyle of this population. Furthermore, these authors correlate the highest score on the Hamilton Depression Rating Scale among HIV individuals classified as "missed dose"(32).

The retention in care was the most critical point of the cascade, in which $58.3 \%$ of the diagnosed cases performed consultations or tests regularly in the evaluated period, with no distinction between genders $(p=0.486)$. In a public hospital in Argentina, the percentage of retention was $65.5 \%{ }^{(30)}$, and, in the Bahamas, it was $32 \%{ }^{(33)}$. In both studies, the authors consider the need for possible interventions to fill this important cascade gap.

\section{Study limitations}

The limitations of this study come from difficulties found in studies conducted through secondary sources, therefore susceptible to not complementing the information investigated. In the medical records analyzed, there was a deficiency in some notes, which caused the loss of certain information, especially related to the presence of coinfections and comorbidities, in addition to some serologies, which may reflect underestimated data concerning these variables. On the other hand, the data available in the recording systems - SI-CTC and SISCEL - allowed access to laboratory parameters that allowed the construction of the care cascade and evaluation of the moment of diagnosis.

\section{Contributions to Nursing}

The results of this study bring significant contributions to nursing and the health team, both in the scope of specialized care services and CTCs and in primary health care. In primary health care, because it is the gateway for people who seek some care and where the diagnosis of HIV infection should be made. For CTCS, we alert that diagnosed cases do not always occur at an opportune time, which refers to the need for better dissemination of this HIV diagnosis service. On the other hand, outpatient services need mechanisms to retain diagnosed and admitted cases to services in order to continue treatment, aiming at suppressing viral load to reach the $90-90-90$ goal.

\section{CONCLUSION}

When analyzing the cascade of care from the CTC as well as the sociodemographic, clinical, and laboratory characteristics related to gender, we observed that the highest chance of positivity is among men, younger and who were not in a domestic partnership. Viral load and CD4+T lymphocyte count tests indicated that many cases diagnosed in CTC were late diagnosed. This study shows that, even with all advances in HIV detection, actions and strategies of social mobilization are necessary to encourage the search and knowledge of the serological condition of individuals, aiming to promote the early diagnosis of the disease and ensure timely access to existing therapeutic measures, with a view to the VL suppression, improvement of quality of life and reduction of transmissibility.

\section{REFERENCES}

1. Ministério da Saúde (BR). Diretrizes para organização do CTA no âmbito da Prevenção Combinada e nas Redes de Atenção à Saúde. Ministério da Saúde, Secretaria de Vigilância em Saúde, Departamento de Vigilância, Prevenção e Controle das Infecções Sexualmente Transmissíveis, do HIV/Aids e das Hepatites Virais. - Brasília: Ministério da Saúde, 2017.

2. Joint United Nations Programm on HIV/AIDS-UNAIDS. Global AIDS Update 2016 [Internet] 2016 [cited 2017 Sep 30 ]. Available from: http:// unaids.org.br/wp-content/uploads/2016/07/global-AIDS-update2016_en.pdf

3. Ministério da Saúde (BR). Protocolo Clínico e Diretrizes Terapêuticas para o Manejo da Infecção pelo HIV em Adultos. Brasília: Ministério da Saúde; 2018 [cited 2018 Nov 18]. Available from: http://www.aids.gov.br/pt-br/pub/2013/ protocolo-clinico-e-diretrizes-terapeuticas-para-manejo-da-infeccao-pelo-hiv-em-adultos 
4. Center for Diseases Control and Prevention (CDC). Understanding the HIV care continuum [internet]. 2017 [cited 2018 Feb 20];1-4. Available from: https://www.cdc.gov/hiv/pdf/library/factsheets/cdc-hiv-care-continuum.pdf

5. Ministério da Saúde (BR). Relatório de Monitoramento Clínico do HIV [Internet] Brasília: Ministério da Saúde; 2019 [cited 2019 Mar 05]. Available from: http://www.aids.gov.br/pt-br/pub/2019/relatorio-de-monitoramento-clinico-do-hiv-2019

6. Barros CRS, Zucchi EM, Scraiber LB, França-Junior I. Individual- and contextual-level factors associated with cliente-initiated HIV testing. Rev Bras Epidemiol. 2017;20(3):394-407. doi: 10.1590/1980-5497201700030004

7. Abati PAM, Segurado AC. Testagem anti-HIV e estádio clínico na admissão de indivíduos em serviço de saúde especializado. Pará, Brasil. Rev Saúde Pública. 2015;49:16. doi:10.1590/S0034-8910.2015049004625

8. Fomundam HN, Tesfay AR, Mushipe SA, Mosina MB, Boshielo CT, Nyambi HT, et al. Prevalence and predictors of late presentation for HIV care in South Africa. S Afr Mrd J. 2017;107(12):1058-64. doi: 10.7196/SAMJ.2017.v107i12.12358

9. Griffith DM. "I am a man": manhood, minority men's health and health equity. Ethnicity \& Disease [Internet]. 2015[cited 2018 Aug 01];25(3):287-93. Available from: https://www.ncbi.nlm.nih.gov/pmc/articles/PMC4671414/pdf/ethndis-25-287.pdf

10. Womack J, Herieka E, Gompels M, Callaghan S, Burt E, Davies CF, et al. A novel strategy to reduce very late HIV diagnosis in high-prevalence areas in South-West England: serious incident audit. J Public Health. 2017;39(1):170-6. doi: 10.1093/pubmed/fdw007

11. Ferreira RFG, Prado Neto SC, Santana NC, Guimarães DA, Oliveira CDL. Gender Differences in Risk Factors for Delayed Diagnosis of HIV/AIDS in a Midsized City of Brazil. J Int Assoc Provid AIDS Care. 2016;15(2):135-40. doi: 10.1177/2325957414553845

12. Ministério da Saúde (BR). Secretária de Vigilância em Saúde. Departamento de DST, HIV e Hepatites Virais. Protocolo Clínico e Diretrizes Terapêuticas para o Manejo da Infecção pelo HIV em Adultos. Brasília: Ministério da Saúde; 2015.

13. Ministério da Saúde (BR). Secretaria de Vigilância em Saúde. Boletim Epidemiológico HIV AIDS [Internet]. Brasília: Ministério da Saúde; 2017 [cited 2019 May 20];49(53):1-72. Available from: http://www.aids.gov.br/pt-br/pub/2018/boletim-epidemiologico-hivaids-2018

14. Estavela AJ, Seidl EMF. Vulnerabilidades de gênero, práticas culturais e infecção pelo HIV em Maputo. Psicol Soc Belo Horizonte. 2015;27(3):569-78. doi.org/10.1590/1807-03102015v27n3p569

15. Silva WS, Oliveira FJ, Serra MA, Rosa CR, Ferreira AG. Fatores associados ao uso de preservativo em pessoas vivendo com HIV/AIDS. Acta Paul Enferm. 2015;28(6):587-92. doi: 10.1590/1982-0194201500096

16. Joint United Nations Programm on HIV/AIDS-UNAIDS. Relatório Informativo Julho 2018. [Internet]. 2018 [cited 2018 Jul 28]. Available from: https://unaids.org.br/wp-content/uploads/2018/07/2018_07_17_Fact-Sheet_miles-to-go.pdf

17. Bastos DC, Paiva MS, Carvalho ESS, Rodrigues GRS. Representações sociais da vulnerabilidade de mulheres negras e não negras à infecção pelo HIV/AIDS. Rev Enferm UERJ [Internet]. 2013 [Cited 2016 Jun 10];21:330-6. Available from: https://www.e-publicacoes.uerj.br/index.php/ enfermagemuerj/article/view/7515/5438

18. Mesenburg MA, Wehrmeister FC, Silveira MF. Teste de HIV solicitado e espontâneo: um estudo de base populacional com mulheres de uma cidade do Sul do Brasil. Cad Saúde Pública. 2017;33(10):e00074415. doi: 10.1590/0102-311X00074415

19. Silva RAR, Silva RTS, Nascimento EGC, Gonçalves OP, Reis MM, Silva BCO. Perfil clínico-epidemiológico de adultos HIV-positivo atendidos em um hospital de Natal/RN. Rev Pesqui Cuid Fundam [Internet]. 2016 [cited 2017 Nov 05];8(3):4689-96. Available from: http://www.seer.unirio. br/index.php/cuidadofundamental/article/view/429

20. Kramer SC, Schmidt AJ, Berg RC, Furegato M, Hospers H, Folch C, et al. Factors associated with unprotected anal sex with multiple nonsteady partners in the past 12 months: results from the European Men-Who-Have-Sex-With-Men. BMC Public Health. 2016;16(47):1-12. do $10.1186 / s 12889-016-2691-z$

21. Ministério da Saúde (BR). Guia de Vigilância em Saúde: volume 2 [Internet]. Brasília: Ministério da Saúde, 2017 [cited 2018 Jul 2]. Available from: http://bvsms.saude.gov.br/bvs/publicacoes/guia_vigilancia_saude_volume_2.pdf

22. Center for Diseases Control and Prevention (CDC). Revised surveillance case definitions for HIV infection among adults, adolescents, and children aged[Internet]. 2008 [cited 2016 Nov 08];57(10). Available from: http://www.cdc.gov/mmwr/pdf/rr/rr5710.pdf

23. Mangal TD, Meireles MV, Pascom ARP, Coelho RA, Benzaken AS, Hallett TB. Determinants of survival of people living with HIV/aids on antiretroviral therapy in Brazil 2006-2015. BMC Infect Dis. 2019;19:206. doi: 10.1186/s12879-019-3844-3

24. Silva JAG, Dourado I, Brito AM, Silva CAL. Factors associated with non-adherence to antiretroviral therapy in adults with AIDS in the first six months of treatment in Salvador, Bahia State, Brazil. Cad Saúde Pública. 2015;31(6):1188-98. doi: 10.1590/0102-311X00106914

25. Alves JS, Belo VS, Castro RC, Silva ES. Fatores associados com a soroprevalência de anticorpos lgG e IgM anti-toxoplasma em pessoas com HIV/aids atendidas em um serviço de assistência especializada. J Health Biol Sci. 2016;4(3):145-51. doi: 10.12662/2317-3076jhbs.v4i3.733. p145-151.2016

26. Valentini MB, Toledo MLG, Fonseca MO, Thiersch LMS, Toledo ISBT, Machado FCJ, et al. Evaluation of late presentation for HIV treatment in a reference center in Belo Horizonte, Southeastern Brazil, from 2008 to 2010. Braz J Infect Dis, Salvador. 2015;19(3):253-62 doi: 10.1016/j. bjid.2015.01.005

27. Righetto RC, Reis RK, Reinato LAF, Gir E. Comorbidades e coinfecções em pessoas vivendo com HIV/Aids. Rev Rede Enferm N. 2014;15(6):942-8. doi: 10.15253/2175-6783.2014000600006 
28. Ministério da Saúde (BR). Secretaria de Vigilância em Saúde. Qualiaids: avaliação e monitoramento da qualidade da assistência ambulatorial em AIDS no SUS. Brasília: Ministério da Saúde; 2008.

29. Joint United Nations Programm on HIV/AIDS-UNAIDS. Confronting discrimination: Overcoming HIV-related stigma and discrimination in health-care settings and beyond. Genebra: UNAIDS [Internet]. 2017 [cited 2017 out 10]. Available from: https://reliefweb.int/sites/reliefweb. int/files/resources/confronting-discrimination_en.pdf

30. Cesar C, Blugerman G, Valiente JA, Rebeiro P, Sued O, Fink V, et al. The HIV care cascade in Buenos Aires, Argentina: results in a tertiary referral hospital. Rev Panam Salud Publica [Internet]. 2016 [cited Feb 10];40(6):448-54. Available from: https://www.ncbi.nlm.nih.gov/pmc/ articles/PMC5518480/pdf/nihms873843.pdf

31. Silva RAR, Costa RHS, Braz LCSB, Lucena IA, Ferreira KSF, Duarte FHS. People living with AIDS: Association between nursing diagnoses and sociodemographic/clinical characteristics. Rev Bras Enferm. 2018;71(5):2535-42. doi: 10.1590/0034-7167-2017-0420

32. Tufano CS, Amaral RA, Cardoso LRD, Malbergier A. The influence of depressive symptoms and substance use on adherence to antiretroviral therapy: a cross-sectional prevalence study. SP Med J. 2015;133(3):179-86. doi: 10.1590/1516-3180.2013.7450010

33. Forbes NM, Johnson G, Mortimer A, Martin I, Frankson M, Johnson K, et al. The HIV continuum of care in the Bahamas in 2014. Rev Panam Salud Publica [Internet]. 2016 [cited 2017 Feb 10];40(6):443-7. Available from: https://www.scielosp.org/pdf/rpsp/2016.v40n6/443-447/en 